\title{
Variation in Heat and Radiation Use Efficiency of Rice as Influenced by Different Growing Environments and Genotypes
}

\author{
U.K. Diwan*, J.L. Chaudhary and Deepika Unjan \\ Department of Agrometeorology, Indira Gandhi Krishi Vishwavidyalaya, \\ Raipur-492012 (C.G.), India \\ *Corresponding author
}

\begin{tabular}{|c|c|}
\hline & A B S T R A C T \\
\hline Keywords & \multirow{4}{*}{$\begin{array}{l}\text { Weather and climate greatly influence the agricultural productivity in any region. } \\
\text { Agricultural production and productivity of any region is regulated by the prevailing } \\
\text { climate of that area through temperature, rainfall, light intensity, radiation, sunshine } \\
\text { duration etc. The present experiment was carried to understand the influence of different } \\
\text { growing environments and genotypes on heat unit requirement, heat use efficiency (HUE) } \\
\text { and radiation use efficiency (RUE) in rice at the Instructional cum research Farm, IGKV, } \\
\text { Raipur (C.G.) during Kharif-2013. The experiment was laid out in split plot design with } \\
\text { five treatments and each treatment replicated three times. The results revealed that the } \\
\text { growing environments greatly affected the total dry matter production. Radiation use } \\
\text { efficiency and heat use efficiency both were recorded maximum in crop sown on } 15^{\text {th }} \text { June } \\
\left(\mathrm{D}_{1}\right) \text {. In terms of genotypes heat use efficiency (HUE) was maximum in Mahamaya and } \\
\text { radiation use efficiency (RUE) was maximum in MTU-1010. }\end{array}$} \\
\hline $\begin{array}{l}\text { Rice, Growing } \\
\text { environments, Heat } \\
\text { use efficiency, } \\
\text { Radiation use } \\
\text { efficiency. }\end{array}$ & \\
\hline Article Info & \\
\hline $\begin{array}{l}\text { Accepted: } \\
\text { 04 September } 2017 \\
\text { Available Online: } \\
\text { 10 November } 2017\end{array}$ & \\
\hline
\end{tabular}

\section{Introduction}

Rice is the most consumed cereal grain in the world constituting the dietary staple food of more than half of the world population. Apart from food rice is intimately involved in the culture as well as economy of many societies. Rice is the most consumed cereal grain in the world constituting the dietary staple food of more than half of the world population. Apart from food rice is intimately involved in the culture as well as economy of many societies. Rice a member of the family Poaceae originated from South East Asia and in Asia where more than 90 per cent of world's rice is produced and consumed ( $\mathrm{Li}$ and $\mathrm{Xu}, 2007$ ) with two countries, China and India, growing more than half of the total crop. Thus rice is immensely important to food security of Asia.
Out of 24 species only two species $O$. glaberima and $O$. sativa are cultivated. In world, rice has occupied an area of 158.91 million hectares with a total production of 471.8 million metric tonnes.

India is the second largest producer of rice after China having an over of 42.41 million hectares with the production of 104.4 Million metric tons and productivity of 3.6 metric tone per hectare (Anonymous, 2015-16).

Chhattisgarh popularly known as "Rice Bowl of India' occupies an area around 3822.68 thousand hectare and with the production of 4802.4 thousand Mt and productivity of 1322 kg per hectare (Anonymous, 2015). 
Plant growth ceases when temperature exceeds a certain value or drops below a critical minimum regardless of favourable moisture and light (Rao et al., 1999). Thermal time is an independent variable to describe plant development (Dwyer and Stewart, 1986) and it has been used as a tool for characterizing thermal response in different crops (Rajput et al., 1987; Billore et al., 1992). Light levels also have a profound influence on plant growth.

Crops sown on different dates are exposed to different solar duration during the season and this may influence Radiation use efficiency (RUE) through its effect on radiation transmission (Khichar et al., 2000). The result of a study on the effect of different dates of sowing and varieties on phenology, HUE and RUE of rice is presented here.

\section{Materials and Methods}

The experiment was conducted in kharif season (2013) at Research and Instructional farm of Indira Gandhi Krishi Vishwavidyalaya; Raipur situated in Eastern Central part of Chhattisgarh at $21^{0} 16^{\prime} \mathrm{N}$, longitude $81^{\circ} 36^{\prime} \mathrm{E}$ latitude and an altitude of $289.5 \mathrm{~m}$ above mean sea level.

The station experiences a sub humid with mean annual rainfall of about $1175 \mathrm{~mm}$ out of which 87 per cent $(1023.0 \mathrm{~mm})$ rainfall is received during monsoon.

The experiment was conducted with three dates of sowing $\mathrm{D}_{1}$ ( $15^{\text {th }}$ June), $\mathrm{D}_{2}\left(25^{\text {th }}\right.$ June $)$ and $\mathrm{D}_{3}\left(05^{\text {th }}\right.$ July $)$ and transplanted twenty days old rice seedlings at a spacing $20 \times 10$ $\mathrm{cm}$. having taken five varieties viz. Karma Mahsuri, MTU-1010, Mahamaya, Swarna 100:60:40 and Swarna 60:40:40 replicated three times in split plot design. Recommended agronomic practices were adopted for the crop during experiment. During this experiment variety Swarna 60:40:40 treated with under dose of fertilizers as ratio of NPK was 60:40:40. Plant samples were collected from each replication for total dry mass. Growing degree days were computed by using base temperature of $10^{\circ} \mathrm{C}$.

The weekly meteorological data were collected from Agro meteorological Observatory Labhandi, Raipur. The measurements of Heat use efficiency and Radiation use efficiency were calculated according to the following formulae.

\section{Heat use efficiency (HUE)}

$\operatorname{HUE}\left(\mathrm{g} / \mathrm{m} 2 /{ }^{0}\right.$ day $)=\frac{\text { Biomass }\left(\mathrm{g} / \mathrm{m}^{2}\right)}{\left.--\operatorname{GDD}^{0}{ }^{0} \text { days }\right)}$

Where, GDD is growing degree days and calculated by the following formula

$\mathrm{GDD}=\sum[(\mathrm{Tx}+\mathrm{Tn}) / 2-$ Base temperature $]$

\section{Radiation use efficiency (RUE)}

RUE $(\mathrm{gMJ}-1)=$ Biomass $\left(\mathrm{g} / \mathrm{m}^{2}\right) /$ PAR $(\mathrm{M}$ $\mathrm{J} / \mathrm{m}^{2} /$ day)

Where, PAR is cumulative intercepted photo synthetically active radiation.

The photo synthetic active radiation can be calculated by using the following formula

$\mathrm{PAR}=\mathrm{Rs} \mathrm{X} 0.5$

Where,

$\mathrm{Rs}=$ incoming solar radiation $\left(\mathrm{MJm}^{-2}\right)$

The incoming solar radiation can be calculated by the formula

$\mathrm{Rs}=\operatorname{Rs} 0(\mathrm{a}+\mathrm{b} * \mathrm{n} / \mathrm{N})$ 
Where,

Rs0 = Extra terrestrial radiation $\left(\mathrm{MJm}^{-2}\right)$

$\mathrm{n}=$ Bright sunshine hours

$\mathrm{N}=$ Possible sunshine hours

$\mathrm{a}=0.18, \mathrm{~b}=0.55$

\section{Statistical analysis}

All the data were tabulated and analysed statistically as per the procedure suggested by Panse and Sukhatme (1967) and Chandel (1984). The F test was used for judging the significance of the treatment mean at $5 \%$ level. Whenever $\mathrm{F}$ test showed significant difference the differences between treatment means were further tested by using critical difference $(\mathrm{CD})$ value. To compare different mean value of treatments, critical difference (CD) values were calculated as follows:

$\operatorname{Sem} \pm=\sqrt{\boldsymbol{E} \boldsymbol{m} \boldsymbol{s} / \boldsymbol{n}}$

Where,

Sem \pm Standard error of mean
Ems $=$ Error mean square

$\mathrm{n}=$ Number of observations on which the mean values is based

$\mathrm{CD}(5 \%)=\operatorname{Sem} \mathrm{x} \sqrt{2} \times \mathrm{t}$ at $5 \%$ for Error d.f. (2.02).

\section{Results and Discussion}

\section{Yield (q/ha)}

Significantly highest grain yield of 51.59 q/ha was obtained with variety Swarna followed by Karma Mahsuri (49.30 q/ha.) but both were at par and significantly lowest grain yield was found with MTU-1010 (39.81 q/ha.). Significantly highest grain yield was recorded when crop sown on $\mathrm{D}_{1}(48.57 \mathrm{q} / \mathrm{ha})$ followed by $\mathrm{D}_{2}(46.7 \mathrm{q} / \mathrm{ha})$.

The highest straw yield was found with Swarna $(67.51 \mathrm{q} / \mathrm{ha})$ followed by Karma Mahsuri $(64.57 \mathrm{q} / \mathrm{ha})$ which were at par to each other. Crop perform highest straw yield when sown on $\mathrm{D}_{1}(65.53 \mathrm{q} / \mathrm{ha})$ followed by $\mathrm{D}_{2}$ sowing (61.04 q/ha) (Table 1).

Table.1 Yield (q/ha.) of rice varieties under different dates of sowing

\begin{tabular}{|lcc|}
\hline Treatments & Grain yield qha $^{-1}$ & Straw yield qha $^{-1}$ \\
\hline Dates of sowing & & \\
D1(15 June) & 48.57 & 65.53 \\
D2 (25 June) & 46.47 & 61.04 \\
D3 (05 July) & 46.07 & 60.23 \\
SEm \pm & $\mathbf{0 . 4 9}$ & $\mathbf{1 . 0 7}$ \\
CD(p=0.05) & $\mathbf{1 . 9 5}$ & $\mathbf{4 . 2 0}$ \\
Varieties & & \\
V1(Karma Mahsuri) & 49.30 & 64.57 \\
V2(MTU1010) & 39.81 & 55.73 \\
V3(Mahamaya) & 45.79 & 61.13 \\
V4(Swarna 100:60:40) & 51.59 & 67.51 \\
V5(Swarna 60:40:40) & 47.71 & 62.39 \\
SEm \pm & $\mathbf{1 . 3 2}$ & $\mathbf{1 . 6 3}$ \\
CD(p=0.05) & $\mathbf{3 . 8 6}$ & $\mathbf{4 . 7 6}$ \\
\hline
\end{tabular}


Table.2 Radiation use efficiency (RUE) and heat use efficiency (HUE) of rice varieties under different dates of sowing

\begin{tabular}{|lcc|}
\hline Treatments & RUE at maturity $\left(\mathbf{g M J}^{\mathbf{- 1}}\right)$ & HUE at maturity $\left(\mathbf{g} / \mathbf{m}^{\mathbf{2}} \mathbf{0}^{\mathbf{0}}\right.$ day $)$ \\
\hline Dates of sowing & & \\
D1(15 June) & 1.94 & 0.75 \\
D2 (25 June) & 1.83 & 0.68 \\
D3 (05 July) & 1.87 & 0.73 \\
SEm \pm & $\mathbf{0 . 0 1}$ & $\mathbf{0 . 0 1}$ \\
CD(p=0.05) & $\mathbf{0 . 0 5}$ & $\mathbf{0 . 0 9}$ \\
Varieties & & \\
V1(Karma Mahsuri) & 1.87 & 0.72 \\
V2(MTU1010) & 2.09 & 0.76 \\
V3(Mahamaya) & 1.97 & 0.77 \\
V4(Swarna 100:60:40) & 1.84 & 0.72 \\
V5(Swarna 60:40:40) & 1.62 & 0.64 \\
SEm \pm & $\mathbf{0 . 0 3}$ & $\mathbf{0 . 0 1}$ \\
CD(p=0.05) & $\mathbf{0 . 0 8}$ & $\mathbf{0 . 0 3}$ \\
\hline
\end{tabular}

\section{Heat use efficiency $\left(\mathrm{g} / \mathrm{m}^{2} / 0 \mathrm{day}\right)$}

On study of heat use efficiency (Table 2) for understanding critical difference between dates of sowing and varieties, it was found that heat use efficiency (HUE) among dates of sowing is non-significant however the higher value of heat use efficiency (HUE) is found in $\mathrm{D}_{1}\left(15^{\text {th }}\right.$ June) sowing as well as grain yield. Among varieties, heat use efficiency is found significantly higher in cultivar Mahamaya $\left(\mathrm{V}_{3}\right)$ which is significantly higher than Karma mahsuri, Swarna 100:60:40 and Swarna 60:40:40. It is further interpreted that effect of fertilizer dose was significant as heat use efficiency (HUE) was significantly higher in cultivar Swarna100:60:40 $\left(\mathrm{V}_{4}\right)$ as compared to Swarna60:40:40 $\left(\mathrm{V}_{5}\right)$.

\section{Radiation use efficiency $\left(\mathrm{gMJ}^{-1}\right)$}

On study of radiation use efficiency (Table 2) it was found that radiation use efficiency in $\mathrm{D}_{2}\left(15^{\text {th }}\right.$ June $)$ sowing was significantly higher as compared to $\mathrm{D}_{2}\left(25^{\text {th }}\right.$ June) sowing and $\mathrm{D}_{3}$ $\left(05^{\text {th }} \mathrm{July}\right)$ sowing, these two treatments being at par. In varieties MTU-1010 ( $\left.\mathrm{V}_{2}\right)$ having highest radiation use efficiency (RUE) which was significantly higher than other varieties. In terms of radiation use efficiency (RUE) second now is of variety Mahamaya $\left(V_{3}\right)$ which is significantly higher than Karma mahsuri $\left(\mathrm{V}_{1}\right)$ and Swarna100:60:40. Even effect of fertilizer dose is showing significant results with Swarna100:60:40 indicating significantly higher radiation use efficiency (RUE) as compared to Swarna60:40:40. $\mathrm{D}_{1}$ ( $15^{\text {th }}$ June) sowing is having higher radiation use efficiency (RUE) as well as higher grain yield which means radiation use efficiency (RUE) can be directly co-related with grain yield.

\section{Acknowledgement}

I am greatly indebted to Mr. J. L. Chaudhry (Sr. Scientist) and my dear colleagues, seniors and all staff of the Departmnet of Agrometeorology, IGKV, Raipur for their kind assistance during the period of study.

\section{References}

Billore, S.D., Mishra, V.H., Holker, S. And Bagal, M. 1992. Heat Use efficiency in soybeans. Res Devel. Reporter, 9:73-78 
Dwyer, L.M. and Stewart, D. W. 1986. Leaf area development in field grown maize. Agron. J., 78:334-348

Khichar, M.L., Yogesh, C.Y., Bishnoi,O,P and Ram Niwas.2000. Radiation Use efficiency of musterd as influenced by sowing dates, plant spacing and cultivar. J. Agrometeorol., 2:97-99.

Lee, J.T., Kim, D.U., Yun, S.H. and Im, J.N. 1991. Regional differences of solar energy efficiency to produce dry matter of rice (Oryza sativa L.) under field conditions in Korea. Research Reports of the Rural Development Administration, Rice. 33(1), 62-73.

Rajput, R.P., Deshmukh, M.R. and Paradekar, V.k. 1987. Accumulated heat units and phonological relationship in wheat as influenced by planting dates under late sown condition. J. Agron. Crop Sci., 159:345-349.

Rao, V.U.M., Diwan Singh and Raj Singh 1999. Heat use efficiency of winter crops in Haryana. J. Agrometeorol., $1: 143-148$.

\section{How to cite this article:}

Diwan, U.K., J.L. Chaudhary and Deepika Unjan. 2017. Variation in Heat and Radiation Use Efficiency of Rice as Influenced by Different Growing Environments and Genotypes. Int.J.Curr.Microbiol.App.Sci. 6(11): 48-52. doi: https://doi.org/10.20546/ijcmas.2017.611.006 